\title{
Mycoplasma iowae: relationships among oxygen, virulence, and protection from oxidative stress
}

\author{
Rachel E Pritchard ${ }^{1,2}$ and Mitchell F Balish ${ }^{1 *}$
}

\begin{abstract}
The poultry-associated bacterium Mycoplasma iowae colonizes multiple sites in embryos, with disease or death resulting. Although M. iowae accumulates in the intestinal tract, it does not cause disease at that site, but rather only in tissues that are exposed to atmospheric $\mathrm{O}_{2}$. The activity of $M$. iowae catalase, encoded by katE, is capable of rapid removal of damaging $\mathrm{H}_{2} \mathrm{O}_{2}$ from solution, and katE confers a substantial reduction in the amount of $\mathrm{H}_{2} \mathrm{O}_{2}$ produced by Mycoplasma gallisepticum katE transformants in the presence of glycerol. As catalase-producing bacteria are often beneficial to hosts with inflammatory bowel disease, we explored whether $M$. iowae was exclusively protective against $\mathrm{H}_{2} \mathrm{O}_{2}$-producing bacteria in a Caenorhabditis elegans model, whether its protectiveness changed in response to $\mathrm{O}_{2}$ levels, and whether expression of genes involved in $\mathrm{H}_{2} \mathrm{O}_{2}$ metabolism and virulence changed in response to $\mathrm{O}_{2}$ levels. We observed that $M$. iowae was in fact protective against $\mathrm{H}_{2} \mathrm{O}_{2}$-producing Streptococcus pneumoniae, but not $\mathrm{HCN}$-producing Pseudomonas aeruginosa, and that $\mathrm{M}$. iowae cells grown in $1 \% \mathrm{O}_{2}$ promoted survival of $C$. elegans to a greater extent than $M$. iowae cells grown in atmospheric $\mathrm{O}_{2}$. Transcript levels of an $M$. iowae gene encoding a homolog of Mycoplasma pneumoniae CARDS toxin were 5-fold lower in cells grown in low $\mathrm{O}_{2}$. These data suggest that reduced $\mathrm{O}_{2}$, representing the intestinal environment, triggers $M$. iowae to reduce its virulence capabilities, effecting a change from a pathogenic mode to a potentially beneficial one.
\end{abstract}

\section{Introduction}

$\mathrm{H}_{2} \mathrm{O}_{2}$ is a dangerous reactive oxygen species (ROS) involved in both pathogenesis and defense against infectious agents. Bacteria may be exposed to multiple sources of $\mathrm{H}_{2} \mathrm{O}_{2}$ during infection, including macrophages, which produce a variety of ROS that damage and degrade bacteria. A variety of bacterial pathogens can also produce $\mathrm{H}_{2} \mathrm{O}_{2}$ as a means of causing damage to host tissues [1,2], and some disease states stem from exposure of tissues to ROS including $\mathrm{H}_{2} \mathrm{O}_{2}$. In particular, in inflammatory bowel disease (IBD), a growing problem in humans in developed countries with a prevalence of $10-20 \%$ [3], a direct correlation between increased ROS production and damage to gut epithelial cells has been reported [4-7].

The enzyme catalase catalyzes degradation of $\mathrm{H}_{2} \mathrm{O}_{2}$ [8]. The production of catalase by microbes can benefit both the microorganisms themselves and a host organism with which they associate. Catalase can protect catalase-producing bacteria from environmental $\mathrm{H}_{2} \mathrm{O}_{2}$

\footnotetext{
*Correspondence: balishmf@miamioh.edu

'Department of Microbiology, Miami University, Oxford, OH 45056, USA

Full list of author information is available at the end of the article
}

and prolong infection. As for the host, several reports have examined the ability of catalase-expressing probiotic bacteria to decrease IBD symptoms [9]. In a murine trinitrobenzenesulfonic acid-induced Crohn's disease model, administration of Lactobacillus casei engineered to express catalase results in faster recovery from initial weight loss, increased gut enzyme activity, and decreased intestinal inflammation as compared with mice infected with wild-type or no bacteria [10]. Similar bacteria decrease cecal and colonic inflammation in mice treated with dextran sodium sulfate to induce moderate colitis [11].

Mycoplasma iowae is a catalase-positive bacterium that infects poultry animals, primarily turkeys but also occasionally chickens $[12,13]$. The most common outcome of naturally-occurring $M$. iowae infection in turkeys is late embryo mortality, with a $2-5 \%$ reduction in hatchability, and leg abnormalities in offspring [14-16]. Symptoms commonly associated with experimental infection include airsacculitis, stunting, poor feathering, and leg and joint problems $[14,16]$. The $M$. iowae catalase gene, $k a t E$, confers both catalase activity and a significant reduction in $\mathrm{H}_{2} \mathrm{O}_{2}$ production upon Mycoplasma 
gallisepticum, a robust $\mathrm{H}_{2} \mathrm{O}_{2}$ producer that elaborates no other known toxins $[13,17,18]$. It is unclear how $M$. iowae causes disease, but in addition to its attachment organelle-mediated adherence and motility functions [19], its genome encodes potential virulence factors, including two closely linked genes encoding proteins similar to Mycoplasma pneumoniae CARDS toxin [13], an ADPribosylating toxin that is associated with many of the symptoms of M. pneumoniae infection [20-22].

Interestingly, $M$. iowae colonizes a variety of body sites with a range of $\mathrm{O}_{2}$ concentrations. It has been isolated from the cloacae of healthy poults and mature turkeys $[23,24]$, but also infects the chorioallantoic membrane and a variety of organs in embryos [25], which accounts for the morbidity and mortality associated with $M$. iowae. Significantly, $M$. iowae also has a pronounced tendency to colonize the gut with no ill effects. Following yolk sac inoculation of eight-day-old turkey embryos, $M$. iowae can be detected in the small intestines, with bacteria most often attaching to microvilli [25]. Oral inoculation of dayold poults with $M$. iowae results in bacteria present in both the feces and intestinal wall for at least 21 days postinoculation, and no differences in fecal appearance or cloaca temperature as compared to control birds [26]. The gut is a very low- $\mathrm{O}_{2}$ environment [27], whereas in ovo embryos, which are commonly damaged by $M$. iowae, are exposed to atmospheric $\mathrm{O}_{2}$ due to eggshell permeability [28]. It is intriguing that $M$. iowae infection at aerobic sites, but apparently not the gut, causes disease, leading us to suspect that $\mathrm{O}_{2}$ might play a role in regulating expression of $M$. iowae virulence factors, resulting in different outcomes at different body sites.

Differential gene expression regulation exists in a variety of mycoplasma species despite their reduced genomes. The $M$. pneumoniae promoters for acetate kinase and lactate dehydrogenase are strongly induced in the presence of glucose and glycerol, respectively [29]. M. pneumoniae lipoprotein genes are also differentially expressed in response to exposure to host cells, $\mathrm{H}_{2} \mathrm{O}_{2}$, and low $\mathrm{pH}$ [30]. Multiple forms of regulation occur in Mycoplasma hyopneumoniae in response to heat shock [31], iron deprivation [32], $\mathrm{H}_{2} \mathrm{O}_{2}$ treatment [33], and infection of pigs [34]. The means by which most of these regulatory events occur is unknown.

In this study we examined the ability of $M$. iowae, by virtue of its catalase activity, to offer protection to a model host from $\mathrm{H}_{2} \mathrm{O}_{2}$ stress, and to test whether $M$. iowae experiences differential regulation of catalase as well as possible virulence-associated genes in response to changes in $\mathrm{O}_{2}$ level. We used Caenorhabditis elegans bioassays, developed previously as a model for use with $M$. iowae [13], and reverse transcription-quantitative polymerase chain reaction (RT-qPCR) of selected candidate virulenceassociated genes. Our results indicate that catalase contributes to $M$. iowae being protective toward the host against $\mathrm{H}_{2} \mathrm{O}_{2}$-producing organisms, even though catalase activity is reduced under conditions of low $\mathrm{O}_{2}$. They also indicate that $M$. iowae grown in low $\mathrm{O}_{2}$ results in increased survival of C. elegans upon co-incubation as compared with $M$. iowae grown in atmospheric conditions, accompanied by a 5 -fold decrease in expression of at least one of the CARDS toxin-like protein genes.

\section{Materials and methods}

\section{Bacterial strains and growth conditions}

Mycoplasma strains used include $M$. iowae serovar $\mathrm{K}$ strain DK-CPA, M. gallisepticum $\mathrm{R}_{\mathrm{low}}$, and M. gallisepticum $\mathrm{R}_{\text {low }}$ transformant 56A. For M. gallisepticum and for aerobic growth of $M$. iowae, all strains were grown at $37^{\circ} \mathrm{C}$ in $175-\mathrm{cm}^{2}$ tissue culture flasks containing $50 \mathrm{~mL}$ of SP-4 broth [35] to mid-log phase. Transformant 56A was grown in the presence of $4 \mu \mathrm{g} \mathrm{mL}^{-1}$ tetracycline. SP-4 broth for samples grown in low $\mathrm{O}_{2}$ was allowed to equilibrate with a $1 \% \mathrm{O}_{2} / 99 \% \mathrm{~N}_{2}$ gas mix overnight. Following equilibration, $50 \mathrm{~mL}$ of broth was aliquotted into glass bottles that were capped with rubber stoppers in which cultures were grown to mid-log phase at $37^{\circ} \mathrm{C}$.

Escherichia coli DH5 $\alpha$ was grown in Luria broth (LB) with $100 \mu \mathrm{g} \mathrm{mL} \mathrm{m}^{-1}$ ampicillin at $37^{\circ} \mathrm{C}$ in a shaking incubator. A Streptococcus pneumoniae obtained from the Miami University Department of Microbiology stock collection was grown at $37^{\circ} \mathrm{C}$ without shaking in brain heart infusion (BHI) broth. Pseudomonas aeruginosa strain PAO1, also from the Miami University Department of Microbiology stock collection, was grown at $37{ }^{\circ} \mathrm{C}$ with shaking in LB broth.

\section{Preparation of cell lysates and protein analysis}

Fifty- $\mathrm{mL}$ cultures of mycoplasma cells were collected by centrifugation at $20000 \times g$ for $20 \mathrm{~min}$ and washed three times with cold phosphate-buffered saline (PBS). Cells were resuspended in $1 \mathrm{~mL}$ cold PBS containing $1 \%$ sodium dodecyl sulfate using a 25 -gauge syringe and incubated at $37{ }^{\circ} \mathrm{C}$ for $30 \mathrm{~min}$. Cell lysates were stored at $-80{ }^{\circ} \mathrm{C}$. Protein concentration in cell lysates was determined using bicinchoninic acid assays (Pierce Biotechnology Inc.).

\section{Catalase enzyme activity}

Catalase activity was measured in whole cell lysates of M. iowae using the Amplex Red Catalase Assay kit (Invitrogen). Catalase activity was normalized to total protein concentration in cell lysate samples. Statistical significance of results was calculated using unpaired Student's $T$-test. Results represent two biological replicates from each condition with four technical replicates each. 


\section{$\mathrm{H}_{2} \mathrm{O}_{2}$ assays}

Methods were adapted from Hames et al. [36]. For $S$. pneumoniae assays, colonies grown on $\mathrm{BHI}$ agar plates were picked and grown overnight in $5 \mathrm{~mL}$ of $\mathrm{BHI}$ broth at $37^{\circ} \mathrm{C}$ without shaking. Cultures were diluted 1:100 in pre-warmed $\mathrm{BHI}$ broth and grown to mid-log phase at $37{ }^{\circ} \mathrm{C}$ without shaking $\left(\mathrm{OD}_{620}=0.2-0.3\right)$. Cells were collected by centrifugation at $10000 \times g$ for $6 \mathrm{~min}$ and washed three times in cold HNM buffer $(67.6 \mathrm{mM}$ HEPES, pH 7.3, $140 \mathrm{mM} \mathrm{NaCl}$, and $7 \mathrm{mM} \mathrm{MgCl} 2 . \mathrm{H}_{2} \mathrm{O}_{2}$ levels were measured using colorimetric test strips (EM Quant, range $0.5-25 \mathrm{mg} \mathrm{L}^{-1}$ ). Four biological replicates were examined. Statistical significance was calculated using unpaired Student's T-test.

To determine $\mathrm{H}_{2} \mathrm{O}_{2}$ production by mycoplasmas alone, 50-mL cultures of mycoplasma cells were grown to mid-log phase. Cells were collected by centrifugation at $20000 \times g$ for $20 \mathrm{~min}$ and washed three times in cold HNM buffer. Following resuspension in the same buffer to an $\mathrm{OD}_{550}=1.0$, aliquots of $1 \mathrm{~mL}$ were added to 24well plates with $500 \mu \mathrm{M}$ or $1 \mathrm{mM}$ sucrose and incubated at room temperature for $24 \mathrm{~h} . \mathrm{H}_{2} \mathrm{O}_{2}$ levels were measured and statistical analysis was performed as described above. Two biological replicates, each with 2 technical replicates, were examined.

To determine $\mathrm{H}_{2} \mathrm{O}_{2}$ production by $S$. pneumoniae when using mycoplasma cells as a source of carbohydrates, both bacteria were grown independently and collected as described above. One-mL aliquots were placed in 24-well plates that contained S. pneumoniae at an $\mathrm{OD}_{620}=0.05$ and mycoplasmas at an $\mathrm{OD}_{550}=1.0$ with no sucrose. Samples were incubated at room temperature for $24 \mathrm{~h} . \mathrm{H}_{2} \mathrm{O}_{2}$ levels were measured and statistical analysis was performed as described above. Three biological replicates were examined.

\section{C. elegans growth conditions}

All assays were performed with $C$. elegans strain N2 (Bristol). Nematodes were cultured using standard practices [37]. Briefly, worms were cultured on nematode growth media plates seeded with E. coli OP50 as a food source at room temperature on the benchtop.

\section{C. elegans survival assays}

Plates containing large, gravid nematodes were treated with hypochlorite solution to obtain sterile eggs using standard procedures [37]. Eggs were hatched overnight in $10 \mathrm{~mL}$ of $\mathrm{M} 9$ buffer with gentle shaking to obtain L1 larvae. L1 larvae were washed with M9 buffer and aliquotted into 24-well plate wells. The number of live larvae per well (indicated by movement) was counted prior to the addition of samples to a final volume of $1 \mathrm{~mL}$. Plates were incubated at room temperature for the designated time, at which time live nematodes were counted again to measure survival. They were considered dead if no movement was observed in response to shaking or tapping the plate. Following the 24-h incubation period, $\mathrm{H}_{2} \mathrm{O}_{2}$ levels were also recorded with the use of colorimetric test strips as described above. For long-term assays, plates were wrapped in parafilm to prevent evaporation of liquid during the extended incubation time required for the experiment. Long-term assay results represent two biological replicates from each condition with six technical replicates each. Statistical significance of results was calculated using unpaired Student's T-test, with $p<0.05$ being regarded as significant.

For mycoplasma samples, cells were collected and washed as described for $\mathrm{H}_{2} \mathrm{O}_{2}$ assays. M. iowae cells tested alone were resuspended to various $\mathrm{OD}_{550}$ values and incubated with $C$. elegans larvae in the presence of the indicated concentrations of $\mathrm{H}_{2} \mathrm{O}_{2}$. Assays examining protection from abiotic $\mathrm{H}_{2} \mathrm{O}_{2}$ were performed with mycoplasma cells resuspended to an $\mathrm{OD}_{550}=1.0$ in the presence of $8 \mathrm{mg} \mathrm{L} \mathrm{m}^{-1} \mathrm{H}_{2} \mathrm{O}_{2}$. Three biological replicates, each with 3-4 technical replicates, were examined.

For assays with $S$. pneumoniae, bacteria were grown and harvested as described for $\mathrm{H}_{2} \mathrm{O}_{2}$ assays. Samples were added to $C$. elegans larvae with $S$. pneumoniae resuspended to $\mathrm{OD}_{620}=0.05$ (approximately $1.1 \times 10^{7} \mathrm{CFUs}$ ), mycoplasmas resuspended to $\mathrm{OD}_{550}=1.0$ (approximately $1.2 \times 10^{9} \mathrm{CFUs}$ for $M$. iowae), and $500 \mu \mathrm{M}$ sucrose. Three biological replicates, each with 2 technical replicates, were examined.

For assays with $P$. aeruginosa, colonies grown on LB agar plates were picked and grown overnight in $5 \mathrm{~mL}$ of LB broth at $37{ }^{\circ} \mathrm{C}$ in a shaking incubator. Cultures were diluted 1:100 in pre-warmed LB broth and grown to midlog phase at $37{ }^{\circ} \mathrm{C}$ and $200 \mathrm{rpm}\left(\mathrm{OD}_{600}=0.4\right)$. Cells were pelleted by centrifugation at $10000 \times g$ for $10 \mathrm{~min}$ and washed three time with cold buffer containing $20 \mathrm{mM} \mathrm{L}$ glutamate, $5 \mathrm{mM} \mathrm{K} \mathrm{KPO}_{4}, 5 \mathrm{mM} \mathrm{NaH} \mathrm{PO}_{4}, 2 \mathrm{mM}$ $\mathrm{MgSO}_{4} \cdot 7 \mathrm{H}_{2} \mathrm{O}, 0.02 \mathrm{mM} \mathrm{FeCl}{ }_{3}, 12.5 \mathrm{mM}$ glycine, and $50 \mathrm{mM}$ Tris, pH 7.5 [38]. P. aeruginosa samples tested alone with worms were resuspended to $\mathrm{OD}_{650}=0.1,0.05$, and 0.01 in the same buffer. For assays performed in combination with mycoplasmas, $P$. aeruginosa was used at $\mathrm{OD}_{650}=0.1$ (approximately $1.1 \times 10^{8} \mathrm{CFUs}$ ). Mycoplasmas were washed and resuspended in the same buffer as $P$. aeruginosa and used at an $\mathrm{OD}_{550}=1.0$. Three biological replicates, each with $2-4$ technical replicates, were examined.

\section{Sequence analysis}

Predicted amino acid sequences for $M$. iowae CARDS1 and CARDS2 [13] and M. pneumoniae CARDS toxin [39] were aligned to one another with BLAST. 


\section{RNA isolation and quantification}

RNA was isolated from $M$. iowae cells using TRI reagent (Sigma). Briefly, cells were collected by centrifugation at $20000 \times g$ for $20 \mathrm{~min}$. Following resuspension of cell pellets in TRI reagent, RNA was extracted with chloroform, pelleted with isopropanol, and washed with 75\% ethanol. RNA was resuspended in 100-300 $\mu \mathrm{L}$ DEPCtreated water and stored at $-20{ }^{\circ} \mathrm{C}$. To eliminate DNA contamination, samples were treated with DNase I (Invitrogen or QIAGEN) according to the manufacturer's instructions. RNA was then cleaned up using the RNeasy Mini Kit (QIAGEN). Elimination of DNA contamination was confirmed by PCR with $g l p F$ primers (Table 1). RNA quality was determined by analysis on an RNA Pico Chip (Agilent Technologies) using a Bioanalyzer 2100 (Agilent Technologies).

\section{Reverse transcription (RT)}

RT was carried out with the Verso cDNA Synthesis Kit (Thermo Scientific) according to the manufacturer's instructions. One hundred ng of RNA was used as starting material and random hexamers were used as primers in reactions with a final volume of $20 \mu \mathrm{L}$. Reactions were incubated at $70{ }^{\circ} \mathrm{C}$ for $5 \mathrm{~min}, 42{ }^{\circ} \mathrm{C}$ for $30 \mathrm{~min}, 95^{\circ} \mathrm{C}$ for $2 \mathrm{~min}$, and then chilled on ice. cDNA synthesis was confirmed by PCR with $g l p F$ primers (Table 1). Controls were performed to exclude the possibility of DNA contamination in which the same reactions were performed with water substituted for Verso Enzyme Mix and RT Enhancer. Control reactions were treated and stored identically to other samples.

\section{Genomic DNA isolation and standard generation}

Genomic DNA was isolated from a 50-mL culture using the QIAamp DNA Mini Kit (QIAGEN). To improve quantification, plasmids were constructed that contained a copy of each gene target. Plasmids were constructed from PCR products amplified from $M$. iowae genomic DNA using gene-specific primers (Table 2) that were ligated into $\mathrm{pCR}^{\circ} 2.1$ (Invitrogen) and transformed into competent E. coli DH5 $\alpha$. Plasmids were isolated from clones with the Zyppy ${ }^{\text {Ti }}$ Plasmid Miniprep Kit (Zymo Research). Insertion was confirmed with digestion by EcoRI and sequence was confirmed using vector-specific primers M13F and M13R (Table 2). Gene copy numbers were calculated using the concentration of each plasmid assuming $1.096 \times 10^{-12} \mathrm{~g} \mathrm{bp}^{-1}$ [40]. Standard curves were generated from ten-fold dilutions of DNA with known copy numbers and were analyzed by qPCR in triplicate.

\section{RT-quantitative PCR (qPCR)}

Each RT-qPCR reaction was done in at least triplicate using two biological replicates. Reactions were performed with PerfeCTa ${ }^{\circ} \mathrm{SYBR}^{\circ}$ Green Supermix (Quanta Biosciences), $1 \mu \mathrm{L}$ of cDNA or DNA template $(5 \mathrm{ng})$, and $300 \mathrm{nM}$ gene-specific primers (Table 1) in a final volume of $25 \mu \mathrm{L}$. Amplification conditions were $5 \mathrm{~min}$ at $95{ }^{\circ} \mathrm{C}$ for $3 \mathrm{~min}$ followed by 40 cycles of $10 \mathrm{~s}$ at $95{ }^{\circ} \mathrm{C}$ and $45 \mathrm{~s}$ at $52{ }^{\circ} \mathrm{C}$. To determine the melting temperature and PCR product specificity, a melting curve was obtained after every run by heating from $50{ }^{\circ} \mathrm{C}\left(2{ }^{\circ} \mathrm{C}\right.$ below $\mathrm{T}_{\mathrm{a}}$ ) to $95{ }^{\circ} \mathrm{C}$. Primer specificity was determined by melting curve analysis and agarose gel electrophoresis of PCR products. Controls with no template or reverse transcriptase were included for each sample during each run. Runs were performed using the CFX Connect (BioRad) and analysis was performed using Bio-Rad CFX Manager 3.0 software (Bio-Rad). The 16S rRNA gene was used for normalization. Statistical analysis of results was calculated using unpaired Student's T-test. MIQE guidelines were followed for performing and reporting experiments [41].

\section{Results}

Catalase confers host protection from peroxigenic bacteria $M$. iowae has an active catalase protein, enabling reduction of $\mathrm{H}_{2} \mathrm{O}_{2}$ by this organism [13]. C. elegans is a wellestablished model for the study of $\mathrm{H}_{2} \mathrm{O}_{2}$-mediated

Table 1 Primers used for qPCR experiments

\begin{tabular}{llll}
\hline Primer Name & Target & Sequence $\left(\mathbf{5}^{\prime}-\mathbf{3}\right)$ & Tm $\left.\mathbf{(}^{\circ} \mathbf{C}\right)$ \\
\hline Ml16Sleft(qPCR) & 16S rRNA gene & CGCAAGACTCACGAGCTAT & 54.6 \\
Ml16Sright(qPCR) & & GGTACAAACTGTCGCAAACC & 54.4 \\
Mlcards1left(qPCR) & cards1 (P271_571) & TGGGTAGAAGCACAGACGT & 56.1 \\
Mlcards1right(qPCR) & & ACTCATCTGCATCTGGGTCA & 55.8 \\
MlglpFleft(qPCR) & glpF (P271_673) & ATCTAGCATGATGGGTGGCG & 57.3 \\
MlglpFright(qPCR) & & TGTCCAAACATTGCTCCTGT & 54.7 \\
MlkatEleft(qPCR) & katE (P271_534) & CGTGTAGTTCATCGAAAGGTG & 54.6 \\
MlkatEright(qPCR) & & CTTCCAGCTTCACCACCAAC & 56.3 \\
Mlsodleft(qPCR) & sodA (P271_491) & ACACAAAGCATCACCAAGCT & 55.2 \\
Mlsodright(qPCR) & & TGATTGTGATGACCTCCACCA & 56.1 \\
\hline
\end{tabular}


Table 2 Primers used for construction and sequencing of qPCR standards

\begin{tabular}{|c|c|c|}
\hline Primer name & Target & Sequence $\left(5^{\prime}-3^{\prime}\right)$ \\
\hline Mlcards1up & cards 1 & ATCGTCTGGTGCATATGCAACAGC \\
\hline Mlcards1down & & ATCGGCTCATGCAAGTGTTGCAGC \\
\hline MlglpFup & $g l p F$ & ATCGGTAGTGCTTITGCACTACAC \\
\hline MlglpFdown & & ATCGCTTCCAATGATTCCACCTCC \\
\hline MlkatEupSall & katE & ATCGGTCGACAAATGCTGCAACAGCTGCAC \\
\hline MlkatEdownSall & & ATCGGTCGACTAAACACAAAATTTGATTTAATCAAAATTCATG \\
\hline Mlsodup & $\operatorname{sod} A$ & ATCGGAACTGGGCCAACAAATGAC \\
\hline Mlsoddown & & ATCGACTTCACATGTCAGTTAGGG \\
\hline M13Forward & Sequencing & GTTGTAAAACGACGGCCACT \\
\hline M13Reverse & & CAGGAAACAGCTATGACC \\
\hline
\end{tabular}

bacterial pathogenicity $[1,2,42]$, and has recently been adapted for use with mycoplasma cells [13]. M. gallisepticum naturally lacks catalase activity, but $M$. gallisepticum katE transformant 56A, which produces $M$. iowae catalase, produces less $\mathrm{H}_{2} \mathrm{O}_{2}$ and kills fewer $C$. elegans larvae in the presence of the peroxigenic molecule glycerol than wild-type $M$. gallisepticum $\mathrm{R}_{\text {low }}$, suggesting a role for catalase in protection from killing [13]. Incubation with $M$. iowae at $\mathrm{OD}_{550}=0.01$ increased survival of C. elegans from $30 \%$ in the absence of bacteria to $50 \%$ (not shown), a reasonable set of conditions for subsequent assays.

In the vertebrate host, bacteria can come into contact with multiple sources of $\mathrm{H}_{2} \mathrm{O}_{2}$, including host immune defense mechanisms and other microbial pathogens $[1,2,43]$. To mimic more closely conditions of $\mathrm{H}_{2} \mathrm{O}_{2}$ exposure in the host and test whether $M$. iowae was protective under these conditions, $C$. elegans survival assays were performed with the use of $\mathrm{H}_{2} \mathrm{O}_{2}$ produced continuously by a biotic source. $S$. pneumoniae is a bacterial pathogen that produces $\mathrm{H}_{2} \mathrm{O}_{2}$ from a variety of substrates including sucrose [44-46], a carbohydrate that $M$. iowae and $M$. gallisepticum are unable to metabolize [17]. When $S$. pneumoniae resuspended to $\mathrm{OD}_{620}=0.05$ was incubated with $500 \mu \mathrm{M}$ sucrose at room temperature for $24 \mathrm{~h}$, $\mathrm{H}_{2} \mathrm{O}_{2}$ accumulated rapidly, reaching maximum levels after $8 \mathrm{~h}$ of incubation, at which point $\mathrm{H}_{2} \mathrm{O}_{2}$ levels remained constant for the duration of the $24 \mathrm{~h}$ period (Figure 1). $M$. iowae or wild-type $M$. gallisepticum resuspended to $\mathrm{OD}_{550}=1.0$ and incubated under the same conditions produced less than $1 \mathrm{mg} \mathrm{L}^{-1} \mathrm{H}_{2} \mathrm{O}_{2}$, respectively, and the same outcome occurred when mycoplasma cells were coincubated with S. pneumoniae in the absence of sucrose (data not shown; see Figure 2B). Based upon these results, C. elegans survival assays were performed with $S$. pneumoniae at $\mathrm{OD}_{620}=0.05$, mycoplasmas at $\mathrm{OD}_{550}=1.0$, and $500 \mu \mathrm{M}$ sucrose.

When incubated with $S$. pneumoniae alone, approximately $6 \%$ of $C$. elegans larvae survived for $24 \mathrm{~h}$ in the presence of sucrose (Figure 2A), correlating with an accumulation of $8 \mathrm{mg} \mathrm{L}^{-1} \mathrm{H}_{2} \mathrm{O}_{2}$ (Figure 2B). In the absence of sucrose, very little $\mathrm{H}_{2} \mathrm{O}_{2}$ accumulated (Figure 2B) and almost all $C$. elegans larvae survived upon incubation with S. pneumoniae (Figure 2A), demonstrating that under these conditions the toxicity was associated primarily with $\mathrm{H}_{2} \mathrm{O}_{2}$. Inclusion of wild-type $M$. gallisepticum with $S$. pneumoniae and sucrose did not significantly alter the amount of C. elegans survival as compared to $S$. pneumoniae alone with sucrose (Figure 2A). However, $\mathrm{H}_{2} \mathrm{O}_{2}$ accumulation decreased to $4.5 \mathrm{mg} \mathrm{L}^{-1}$ (Figure 2B), possibly because of loss of $\mathrm{H}_{2} \mathrm{O}_{2}$ upon reaction with the high number of $M$. gallisepticum cells in suspension. On the other hand, inclusion of catalase-producing $M$. iowae or $M$. gallisepticum transformant 56A resulted in significantly increased amounts of $C$. elegans survival (Figure 2A) and no detectable $\mathrm{H}_{2} \mathrm{O}_{2}$ (Figure 2B). Taken together, these results suggest that catalase enables $M$. iowae to

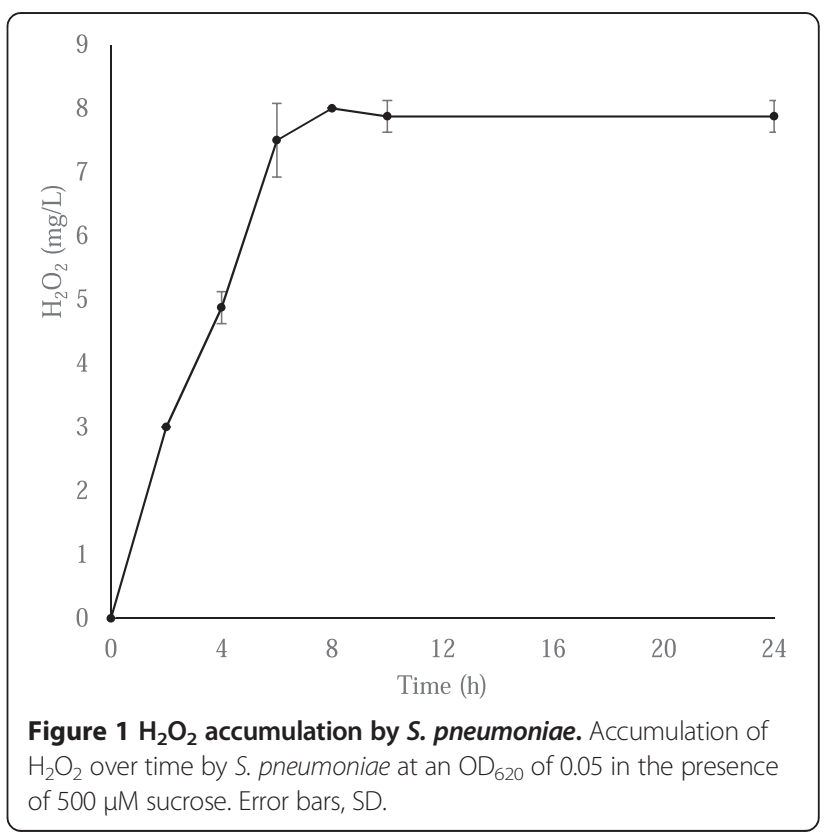




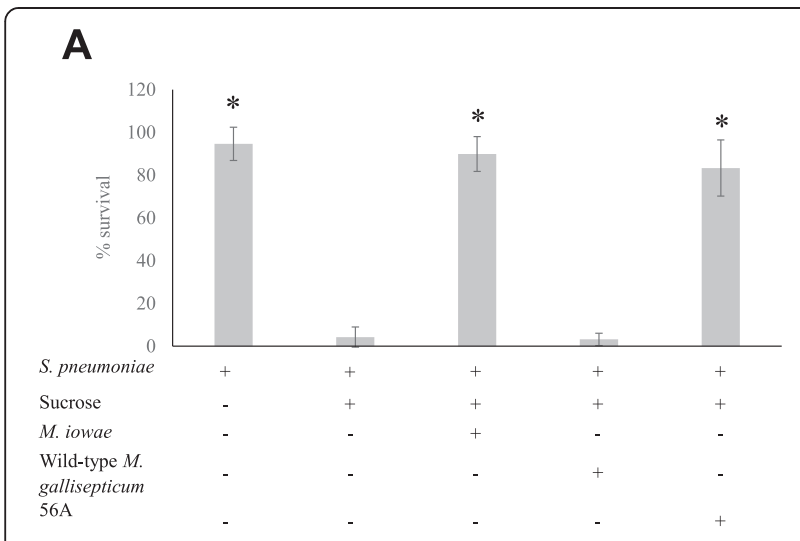

B

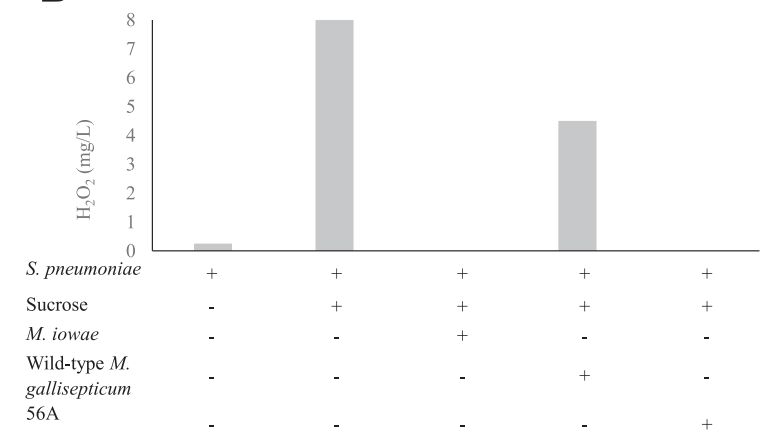

Figure 2 Host protection from S. pneumoniae-produced $\mathrm{H}_{2} \mathrm{O}_{2}$ by catalase-positive mycoplasmas. Survival of $\mathrm{C}$. elegans $(\mathbf{A})$ and amount of $\mathrm{H}_{2} \mathrm{O}_{2}$ remaining (B) at $24 \mathrm{~h}$ upon incubation with $\mathrm{S}$. pneumoniae at $\mathrm{OD}_{620}=0.05$ in the presence of $500 \mu \mathrm{M}$ sucrose. Experiments were performed in triplicate. Results shown are from one representative experiment (B). Error bars, SD. *, statistically significantly different from S. pneumoniae alone with $500 \mu \mathrm{M}$ sucrose $(p<0.05)$.

offer protection from $\mathrm{H}_{2} \mathrm{O}_{2}$ being continually produced by other organisms.

Reasoning that protection by $M$. iowae is due to catalase and therefore might be specific to $\mathrm{H}_{2} \mathrm{O}_{2}$-mediated stress, C. elegans survival assays were repeated with a non- $\mathrm{H}_{2} \mathrm{O}_{2}$ producing pathogen. $P$. aeruginosa $\mathrm{PAO} 1$ produces the toxic molecule $\mathrm{HCN}$ [47], to which C. elegans larvae are highly susceptible; incubation with this bacterial strain typically results in complete killing of larvae $[48,49]$. At $\mathrm{OD}_{650}=0.1, P$. aeruginosa caused almost complete killing of larvae at $24 \mathrm{~h}$ (data not shown). Under these conditions, co-incubation of $C$. elegans with $P$. aeruginosa and any of the mycoplasma strains resulted in no difference in the survival of larvae at $24 \mathrm{~h}$ (Figure 3).

\section{$\mathrm{O}_{2}$-dependent changes in catalase activity and long-term survival of $C$. elegans}

$M$. iowae lives in both aerobic and reduced-oxygen environments in its natural host, but its pathogenicity appears to be limited or non-existent in the gut, where it accumulates but where $\mathrm{O}_{2}$ is low. Therefore, we explored whether $M$. iowae grown under low $\mathrm{O}_{2}$ conditions might be less toxic to host cells. Interestingly, catalase activity of $M$. iowae significantly decreased by $24 \%(p<0.05)$ in low $\mathrm{O}_{2}$ (Figure 4), suggesting that $\mathrm{O}_{2}$ exposure has an impact on catalase activity in $M$. iowae. M. gallisepticum 56A, which offered protection comparable to that of $M$. iowae [13] had $63 \%$ less catalase activity $(p<0.05)$ than $M$. iowae under atmospheric conditions (Figure 4). Therefore the decreased catalase activity in $M$. iowae cells grown in $1 \% \mathrm{O}_{2}$ is unlikely to result in a significant decrease in protection.

Whereas diffusible molecules such as $\mathrm{H}_{2} \mathrm{O}_{2}$ are responsible for damage to C. elegans within the first $48 \mathrm{~h}$ of incubation, the impact of toxins becomes apparent after $48 \mathrm{~h}$ as bacteria are able to establish an infection within the nematode gut [2]. To examine differences in the ability of $M$. iowae to cause damage to its host, longterm $C$. elegans assays were performed with bacterial cells grown under different $\mathrm{O}_{2}$ concentrations. It is important to consider that the C. elegans assay conditions are carried out in a buffer, preventing mycoplasma growth, and at room temperature, which is well below the temperature range at which $M$. iowae can grow. It is therefore very likely that by the end of the incubation with C. elegans, M. iowae cells have no more catalase or putative toxins than they had at the beginning. A repeated measures ANOVA revealed significant differences between the two groups $[F(1,17)=27.39, p<0.05]$. Cells grown aerobically caused nematodes to die much more quickly, with $50 \%$ survival achieved after approximately 5 days as compared to approximately 9 days with cells grown in the presence of $1 \% \mathrm{O}_{2}$, and death of all larvae by 15 days with aerobically-grown $M$. iowae cells as opposed to 20 days with low $\mathrm{O}_{2}$-grown mycoplasmas (Figure 5). These data suggest that $M$. iowae cells are less harmful in low- $\mathrm{O}_{2}$ environments.

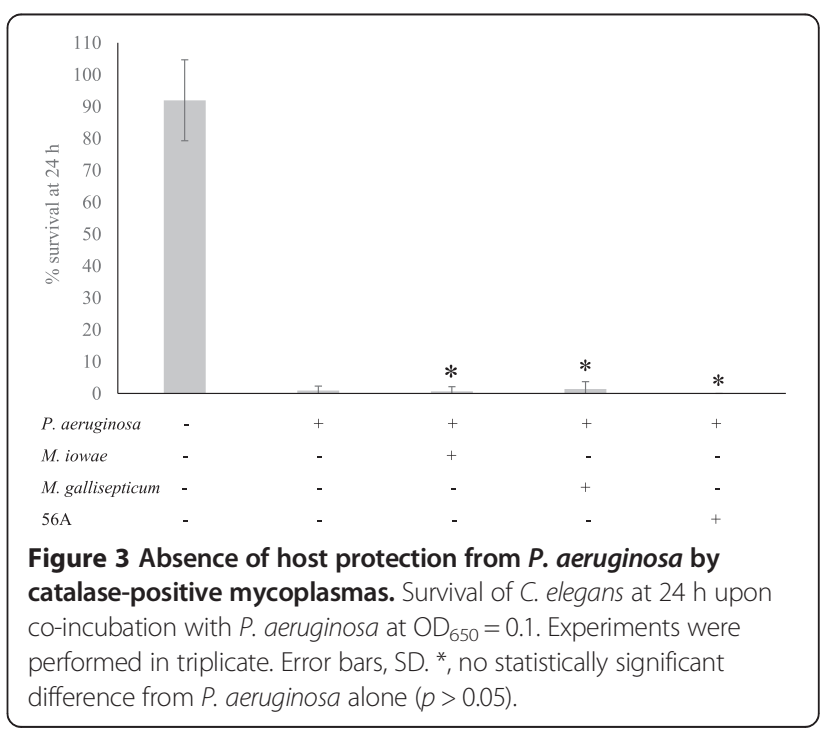




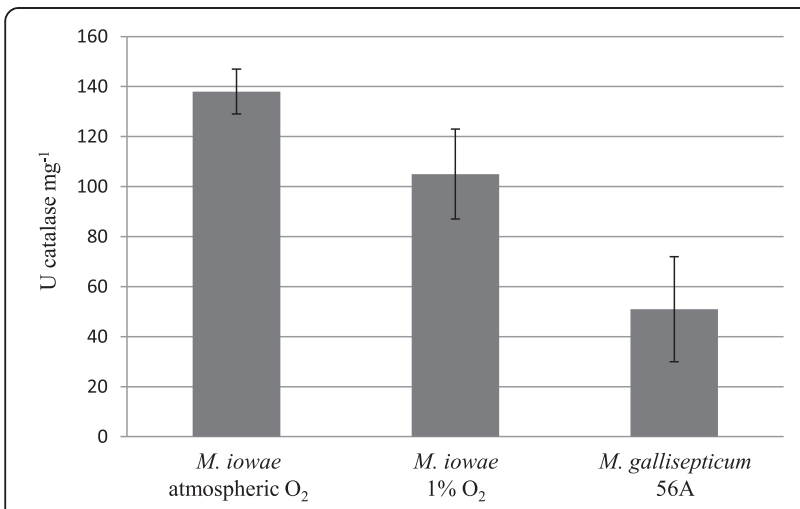

Figure 4 Catalase activity in $M$. iowae and $M$. gallisepticum transformed with katE. Extracts from cells grown under atmospheric conditions or in $1 \% \mathrm{O}_{2}$ were assayed for catalase activity as described in Material and methods. Error bars, SD.

\section{$\mathrm{O}_{2}$ regulation of potential $M$. iowae virulence genes}

Because it is unlikely that a relatively small $\mathrm{O}_{2}$-dependent decrease in $M$. iowae catalase activity was related to increased survival of $C$. elegans, we hypothesized that $M$. iowae genes more directly linked to virulence experienced $\mathrm{O}_{2}$-dependent regulation. Candidate virulence-associated genes were selected for analysis of regulation of expression by $\mathrm{O}_{2}$. Transcription of the potential virulence factors $g l p F$ and cards 1 was examined as well as $k a t E$ and another antioxidant enzyme, sodA. $g l p F$, which allows uptake of glycerol for production of $\mathrm{H}_{2} \mathrm{O}_{2}$, was chosen as a representative of the presumptive glycerol catabolism operon that includes $g l p K$ and $g l p O$. Additionally, $M$. iowae serovar K has two copies of genes homologous to M. pneumoniae CARDS toxin [13]. We examined the predicted amino acid sequences for the proteins encoded by these genes. There are three common motifs shared by many ADP-ribosylating toxins: a conserved arginine for $\mathrm{NAD}^{+}$ binding, a serine-threonine-serine motif to maintain structural integrity of the $\mathrm{NAD}^{+}$binding site, and a catalytic glutamate [20]. These amino acids are all present in $M$. pneumoniae CARDS toxin, which has ADP-ribosyltransferase activity [20]. When both $M$. iowae CARDS toxin homologs were examined (named CARDS1 and CARDS2), some deviations were observed (Figure 6). CARDS2 has a conservative change of the second serine residue in the STS motif to a threonine. CARDS1 contains multiple changes, with substitutions of like charge at the conserved arginine and glutamate residues and less conservative substitutions for two of the three amino acids in the serine-threonine-serine motif. These $M$. iowae homologues have $28 \%$ and $25 \%$ identity, respectively, to the $M$. pneumoniae CARDS toxin sequence. Each M. iowae gene also has 99\% identity to its respective homolog in $M$. iowae serovar I strain 695 [50]. cards1 was chosen despite the greater degree of disparity from M. pneumoniae CARDS toxin

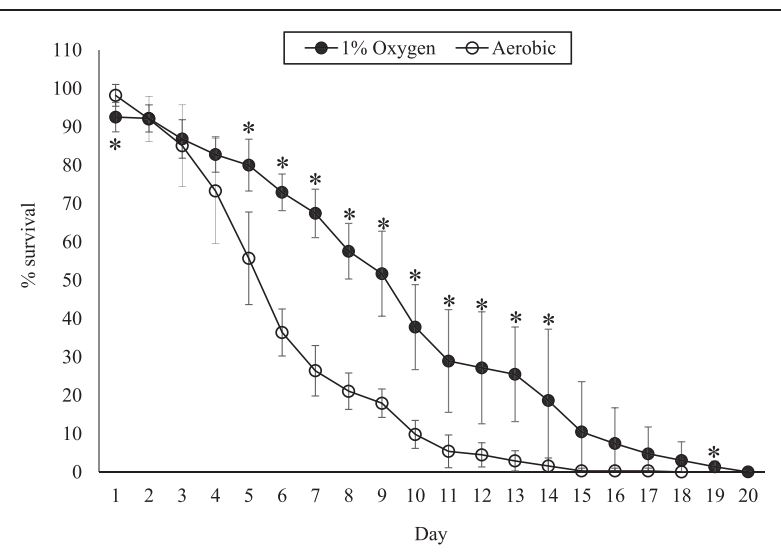

Figure 5 Long-term survival of $C$. elegans when fed $M$. iowae grown aerobically or in the presence of $1 \% \mathrm{O}_{2}$. Error bars, SD. *, statistically significantly different from aerobically-grown $M$. iowae $(p<0.05)$.

since only 20 bases separate cards 1 and cards2, likely making both genes transcriptionally linked.

To examine transcript levels in $M$. iowae cells grown under different $\mathrm{O}_{2}$ concentrations, qPCR was performed (Table 3). Expression of 16S rRNA was used as a control. The putative toxin gene cards1 and the catalase gene katE underwent statistically significant down-regulation in $M$. iowae cells grown in the presence of $1 \% \mathrm{O}_{2}$, with decreases of 4.9- and 5.4-fold, respectively (Table 3). In contrast, $g l p F$ and $\operatorname{sod} A$ did not exhibit significant changes in expression in response to $\mathrm{O}_{2}$ availability. Taken together, these data suggest that $M$. iowae undergoes differential regulation of select genes in response to low $\mathrm{O}_{2}$ conditions. The reduction in cards 1 expression is consistent with reduced pathogenicity in the gut.

\section{Discussion}

Both genome sequences currently available for $M$. iowae $[13,50]$ reveal the presence of a gene for catalase, an $\mathrm{H}_{2} \mathrm{O}_{2}$-degrading enzyme absent from all other published mycoplasma genomes, which produces an active protein [13]. Bacteria can encounter exposure to $\mathrm{H}_{2} \mathrm{O}_{2}$ from a variety of different sources, including other bacterial pathogens as well as the host immune response $[1,2,43]$. Bacteria bearing enzymes that detoxify ROS, including catalase, have been demonstrated to provide benefit to animal hosts in the context of probiotics [9]. Our results support a model wherein protection by $M$. iowae is specific to catalase-mediated reduction of $\mathrm{H}_{2} \mathrm{O}_{2}$ stress, but other mechanisms are also possible. Catalase is specifically implicated in this protection because M. gallisepticum, which does not normally have catalase activity, becomes protective upon transformation with $M$. iowae katE [13], despite 2.7-fold less catalase activity in the $M$. gallisepticum transformant 56A as compared with $M$. iowae. 


$$
\begin{array}{llll}
\text { M. pneumoniae CARDS } & { }^{6} \text { RFVYRVDLR } & { }^{44} \text { RSYFISTSET } & { }^{126} \text { SFAYQREWFTD } \\
\text { M. iowae CARDS1 } & { }^{21} \text { KYVYKIDKR } & { }^{66} \text { RSLLISVFPT } & { }^{145} \text { NFLWQNDWFKI } \\
\text { M. iowae CARDS2 } & { }^{13} \text { RLVYRIDSR } & { }^{58} \text { RSVYVSTTDS } & { }^{144} \text { DFAYQREWIHV }
\end{array}
$$

Figure 6 Alignment of CARDS toxin-like sequences from M. pneumoniae and $\boldsymbol{M}$. iowae. Residues generally conserved in other ADP-ribosylating toxins are bolded and enlarged.

Host-associated bacteria live in the presence of a consortium of other microorganisms, some of which may be $\mathrm{H}_{2} \mathrm{O}_{2}$ producers. We used S. pneumoniae as a model pathogen that produces $\mathrm{H}_{2} \mathrm{O}_{2}$ as an important virulence factor that not only can cause damage to host cells but has also been studied in the context of $C$. elegans [51-53]. Furthermore, S. pneumoniae can inhibit the growth of other bacterial competitors by virtue of its $\mathrm{H}_{2} \mathrm{O}_{2}$ production [54]. The ability of $M$. iowae to protect against $\mathrm{H}_{2} \mathrm{O}_{2}$-mediated damage caused by $S$. pneumoniae, albeit not against other kinds of damage such as that caused by $P$. aeruginosa, suggests that $M$. iowae could be beneficial to its host provided it is not also producing molecules harmful to its host.

$M$. iowae causes damage at multiple sites throughout the body of its natural poultry hosts, including legs, joints, air sac, and feathers [14-16]. However, despite many accounts of detection in and isolation from the gut, no clear-cut reports of disease at this site due to $M$. iowae have been documented [23-26]. Because low $\mathrm{O}_{2}$ concentration is a hallmark of the gut environment that distinguishes it from other sites at which $M$. iowae causes damage and disease [27], we examined the impact of growth in $1 \% \mathrm{O}_{2}$ on $M$. iowae with regard to activities that might be associated with both disease and protection. Our finding that $M$. iowae has an ability to prolong survival when fed to $C$. elegans larvae following growth in $1 \% \mathrm{O}_{2}$ supports the notion that $M$. iowae is not harmful in the gut and might in fact be a beneficial component of the gut microflora. Significantly, at the transcriptional level, this environment causes a significant down-regulation in not only the gene encoding catalase, but also a gene encoding a homolog of CARDS toxin, a causative agent of host damage by $M$. pneumoniae [20,55] and M. penetrans [56].

Table 3 Differences in gene expression as determined by qPCR in response to growth in the presence of $1 \% \mathrm{O}_{2}$

\begin{tabular}{ll}
\hline Gene & Fold-change of down-regulation in response to $\mathbf{1 \%} \mathbf{O}_{\mathbf{2}}^{\mathbf{*}}$ \\
\hline cards 1 & $4.93 \pm 0.78^{\dagger}$ \\
glpF & $1.67 \pm 0.88$ \\
katE & $5.37 \pm 2.60^{\dagger}$ \\
sodA & $1.35 \pm 1.06$ \\
\hline
\end{tabular}

${ }^{*}$ Average \pm SD.

${ }^{\dagger} p<0.05$ compared to aerobic expression as determined by unpaired Student's $T$-test.
These data suggest that $M$. iowae undergoes differential regulation of select genes in response to growth in low $\mathrm{O}_{2}$ environments.

The down-regulation of $k a t E$ in $1 \% \mathrm{O}_{2}$ could be a response to a decreased threat of damage from ROS. Despite this reduction, it is important to consider that the catalase activity in low $\mathrm{O}_{2}$-grown $M$. iowae cells is still 2.1-fold greater than the amount present in M. gallisepticum transformant 56A, which itself still confers significant protection of $C$. elegans exposed to $\mathrm{H}_{2} \mathrm{O}_{2}$ [13]. Therefore, the reduction in $M$. iowae catalase activity in a gut-like environment is not necessarily associated with decreased protection. It is possible that production of catalase facilitates colonization of the gut by $M$. iowae, in parallel with Campylobacter jejuni, which expresses an active catalase that is important for colonization of the poultry intestinal tract [57]. The degree of downregulation of $k a t E$ at the transcription level does not closely match the change in catalase activity in whole cell lysates, with a smaller decrease observed in the latter. The high level of catalase activity might not decrease linearly as the concentration of catalase decreases.

The down-regulation of cards1, a homolog of CARDS toxin, which is likely accompanied by similar downregulation of the very closely linked cards2, may be associated with decreased pathogenicity of $M$. iowae in the gastrointestinal tract. The amount of CARDS toxin produced correlates positively with the amount of host damage caused by M. pneumoniae [55]. Differential expression of toxins in different environments is well-established in diverse bacteria, including clostridia [58], Vibrio cholerae [59], and cyanobacteria [60]. It is conceivable that the environment of the intestine is sufficiently nutritious for $M$. iowae that severe damage to host cells is unwarranted, favoring a strategy in which virulence factors may be used principally in environments in which nutrients are less readily available. In this model, low $\mathrm{O}_{2}$ provides a cue to $M$. iowae that it is in the gut, where it can conserve energy by down-regulating virulence genes, including those encoding the CARDS toxin-like proteins. The similar down-regulation of both cards1 and katE transcript levels when grown in the presence of $1 \% \mathrm{O}_{2}$, on the order of 5 -fold, raises the possibility that a common regulatory mechanism may be acting on both genes, but further work is necessary to elucidate such a mechanism. 


\section{Abbreviations}

ROS: Reactive oxygen species; IBD: Inflammatory bowel disease; RTqPCR: Reverse transcription-quantitative polymerase chain reaction; $\mathrm{BHI}$ : Brain heart infusion; PBS: Phosphate-buffered saline..

\section{Competing interests}

The authors declare that they have no competing interests.

\section{Authors' contributions}

REP carried out all the experimentation, participated in the design of the study, participated in the analysis of the results, and drafted the manuscript. MFB conceived of the study, participated in the design of the study, the analysis of the results, and the writing of the manuscript. Both authors read and approved the final manuscript.

\section{Acknowledgments}

This work was supported by the National Institutes of Health (Public Health Service grant R15 Al073994) to MFB and by an award from the Sigma Xi foundation to REP. We thank A. Bollmann and members of her research group for assistance with low- $\mathrm{O}_{2}$ growth of $\mathrm{M}$. iowae. We thank A. Kiss of the Miami University Center for Bioinformatics and Functional Genomics for training in RNA quantification. We thank C.N. Bialorucki for assistance with quantification of the relationship among $\mathrm{OD}_{550}$ values, colony-forming units, and protein concentrations for mycoplasma species. This work was done in partial fulfillment of REP's doctoral dissertation requirements.

\section{Author details}

${ }^{1}$ Department of Microbiology, Miami University, Oxford, OH 45056, USA. ${ }^{2}$ Present address: Division of Natural Sciences and Mathematics, Kentucky Wesleyan College, Owensboro, KY 42301, USA.

\section{Received: 19 December 2014 Accepted: 5 March 2015}

\section{Published online: 21 March 2015}

\section{References}

1. Bolm M, Jansen WTM, Schnabel R, Chhatwal G (2004) Hydrogen peroxidemediated killing of Caenorhabditis elegans: a common feature of different streptococcal species. Infect Immun 72:1192-1194

2. Moy Tl, Mylonakis E, Calderwood SB, Ausubel FM (2004) Cytotoxicity of hydrogen peroxide produced by Enterococcus faecium. Infect Immun 72:4512-4520

3. Whelan K, Quigley EMM (2013) Probiotics in the management of irritable bowel syndrome and inflammatory bowel disease. Curr Opin Gastroenterol 29:184-189

4. Simmonds NJ, Allen RE, Stevens TR, Van Someren RN, Blake DR, Rampton DS (1992) Chemiluminescence assay of musical reactive oxygen metabolites in inflammatory bowel disease. Gastroenterology 103:186-196

5. Sedghi S, Fields JZ, Klamut M, Urban G, Durkin M, Winship D, Fretland D, Olyaee M, Keshavarzian A (1993) Increased production of luminol and chemiluminescence by the inflamed colonic mucosa in patients with ulcerative colitis. Gut 34:1191-1197

6. Lih-Brody L, Powell SR, Collier KP, Reddy GM, Cerchia R, Kahn E, Weissman GS, Katz S, Floyd RA, McKinley MJ, Fisher SE, Mullin GE (1996) Increased oxidative stress and decreased antioxidant defenses in mucosa of inflammatory bowel disease. Dig Dis Sci 41:2078-2086

7. Keshavarzian A, Banan A, Farhadi A, Komanduri S, Mutlu E, Zhang Y, Fields JZ (2003) Increases in free radicals and cytoskeletal protein oxidation and nitration in the colon of patients with inflammatory bowel disease. Gut $52: 720-728$

8. Switala J, Loewen PC (2002) Diversity of properties among catalases. Arch Biochem Biophys 401:145-154

9. Zhu H, Li YR (2012) Oxidative stress and redox signaling mechanisms of inflammatory bowel disease: updated experimental and clinical evidence. Exp Biol Med 237:474-480

10. LeBlanc JG, del Carmen S, Miyoshi A, Azevedo V, Sesma F, Langella P, Bermúdez-Humarán LG, Watterlot L, Perdigon G, de Moreno de LeBlanc A (2011) Use of superoxide dismutase and catalase producing lactic acid bacteria in TNBS induced Crohn's disease in mice. J Biotechnol 151:287-293

11. Rochat T, Bermúdez-Humarán L, Gratadoux J-J, Fourage C, Hoebler C, Corthier G, Langella P (2007) Anti-inflammatory effects of Lactobacillus casei BL23 producing or not a manganese-dependent catalase on DSS-induced colitis in mice. Microb Cell Fact 6:22
12. Al-Ankari AR, Bradbury JM (1996) Mycoplasma iowae: a review. Avian Pathol 25:205-229

13. Pritchard RE, Prassinos AJ, Osborne JD, Raviv Z, Balish MF (2014) Reduction of hydrogen peroxide accumulation and toxicity by a catalase from Mycoplasma iowae. PLoS One 9:e105188

14. Bradbury JM, Ideris A, Oo TT (1988) Mycoplasma iowae infection in young turkeys. Avian Pathol 17:149-171

15. Trampel DW, Goll F, Jr (1994) Outbreak of Mycoplasma iowae infection in commercial turkey poults. Avian Dis 38:905-909

16. Ley DH, Marusak RA, Vivas EJ, Barnes HJ, Fletcher OJ (2010) Mycoplasma iowae associated with chondrodystrophy in commercial turkeys. Avian Pathol 39:87-93

17. Taylor RR, Mohan K, Miles RJ (1996) Diversity of energy-yielding substrates and metabolism in avian mycoplasmas. Vet Microbiol 51:291-304

18. Papazisi L, Gorton TS, Kutish G, Markham PF, Browning GF, Nguyen DK, Swartzell S, Madan A, Mahairas G, Geary SJ (2003) The complete genome sequence of the avian pathogen Mycoplasma gallisepticum strain $\mathrm{R}_{\text {low. }}$ Microbiology 149:2307-2316

19. Jurkovic DA, Newman JT, Balish MF (2012) Conserved terminal organelle morphology and function in Mycoplasma penetrans and Mycoplasma iowae. J Bacteriol 194:2877-2883

20. Kannan TR, Baseman JB (2006) ADP-ribosylating and vacuolating cytotoxin of Mycoplasma pneumoniae represents unique virulence determinant among bacterial pathogens. Proc Natl Acad Sci U S A 103:6724-6729

21. Hardy RD, Coalson JJ, Peters J, Chaparro A, Techasaensiri C, Cantwell AM, Kannan TR, Baseman JB, Dube PH (2009) Analysis of pulmonary inflammation and function in the mouse and baboon after exposure to Mycoplasma pneumoniae CARDS toxin. PLoS One 4:e7562

22. Medina JL, Coalson JJ, Brooks EG, Winter VT, Chaparro A, Principe MF, Kannan TR, Baseman JB, Dube PH (2012) Mycoplasma pneumoniae CARDS toxin induces pulmonary eosinophilic and lymphocytic inflammation. Am J Respir Cell Mol Biol 46:815-822

23. Jordan FTW, Amin MM (1980) A survey of mycoplasma infections in domestic poultry. Res Vet Sci 28:96-100

24. Jordan FTW (1983) Recovery and identification of avian mycoplasmas. In: Tully JG, Razin S (ed) Methods in Mycoplasmology. Diagnostic Mycoplasmology, vol II. Academic, New York, pp 69-79

25. Mirsalimi SM, Rosendal S, Julian RJ (1989) Colonization of the intestine of turkey embryos exposed to Mycoplasma iowae. Avian Dis 33:310-315

26. Shah-Majid M, Rosendal S (1986) Oral challenge of turkey poults with Mycoplasma iowae. Avian Dis 31:365-369

27. He G, Shankar RA, Chzhan M, Samouilov A, Kuppusamy P, Zweier JL (1999) Noninvasive measurement of anatomic structure and intraluminal oxygenation in the gastrointestinal tract of living mice with spatial and spectral ER imaging. Proc Natl Acad Sci U S A 96:4586-4591

28. Wangensteen OD, Rahn H (1970-1971) Respiratory gas exchange by the avian embryo. Respir Physiol 11:31-45

29. Halbedel S, Eiler H, Jonas B, Busse J, Hecker M, Engelmann S, Stülke J (2007) Transcription in Mycoplasma pneumoniae: analysis of the promoters of the ackA and Idh genes. J Mol Biol 371:596-607

30. Hallamaa KM, Tang S-L, Ficorilli N, Browning GF (2008) Differential expression of lipoprotein genes in Mycoplasma pneumoniae after contact with human lung epithelial cells, and under oxidative and acidic stress. BMC Microbiol 8:124

31. Madsen ML, Nettleton D, Thacker EL, Edwards R, Minion FC (2006) Transcriptional profiling of Mycoplasma hyopneumoniae during heat shock using microarrays. Infect Immun 74:160-166

32. Madsen ML, Nettleton D, Thacker EL, Minion FC (2006) Transcriptional profiling of Mycoplasma hyopneumoniae during iron depletion using microarrays. Microbiology 152:937-944

33. Schafer ER, Oneal MJ, Madsen ML, Minion FC (2007) Global transcriptional analysis of Mycoplasma hyopneumoniae following exposure to hydrogen peroxide. Microbiology 153:3785-3790

34. Madsen ML, Puttamreddy S, Thacker EL, Carruthers MD, Minion FC (2008) Transcriptome changes in Mycoplasma hyopneumoniae during infection. Infect Immun 76:658-663

35. Tully JG, Rose DL, Whitcomb RF, Wenzel RP (1979) Enhanced isolation of Mycoplasma pneumoniae from throat washings with a newly-modified culture medium. J Infect Dis 139:478-482

36. Hames C, Halbedel S, Hoppert M, Frey J, Stülke J (2009) Glycerol metabolism is important for cytotoxicity of Mycoplasma pneumoniae. J Bacteriol 191:747-753 
37. Lewis JA, Fleming JT (1995) Basic culture methods. In: Epstein HF, Shakes DC (ed) Methods in Cell Biology. Caenorhabditis elegans: Modern Biological Analysis of an Organism, vol 48. Academic, Boston, pp 3-29

38. Castric PA (1983) Hydrogen cyanide production by Pseudomonas aeruginosa at reduced oxygen levels. Can J Microbiol 29:1344-1349

39. Himmelreich R, Hilbert H, Plagens H, Pirkl E, Li B-C, Herrmann R (1996) Complete sequence analysis of the genome of the bacterium Mycoplasma pneumoniae. Nucleic Acids Res 24:4420-4449

40. Kong W, Nakatsu CH (2010) Optimization of RNA extraction for PCR quantification of aromatic compound degradation genes. Appl Environ Microbiol 76:1282-1284

41. Bustin SA, Benes V, Garson JA, Hellemans J, Huggett J, Kubist M, Mueller R, Nolan T, Pfaffl MW, Shipley GL, Vandesompele J, Wittwer CT (2009) The MIQE guidelines: minimum information for publication of quantitative realtime PCR experiments. Clin Chem 55:611-622

42. Jansen WTM, Bolm M, Balling R, Chhatwal GS, Schnabel R (2002) Hydrogen peroxide-mediated killing of Caenorhabditis elegans by Streptococcus pyogenes. Infect Immun 70:5202-5207

43. Slauch JM (2011) How does the oxidative burst of macrophages kil bacteria? Still an open ended question. Mol Microbiol 80:580-583

44. Avery OT, Neill JM (1924) Studies on oxidation and reduction by pneumococcus. II. The production of peroxide by sterile extracts of pneumococcus. J Exp Med 39:357-366

45. Spellerberg B, Cundell DR, Sandros J, Pearce BJ, Idänpään-Heikkilä I, Rosenow C, Masure HR (1996) Pyruvate oxidase, as a determinant of virulence in Streptococcus pneumoniae. Mol Microbiol 19:803-813

46. Iyer R, Camilli A (2007) Sucrose metabolism contributes to in vivo fitness of Streptococcus pneumoniae. Mol Microbiol 66:1-13

47. Castric PA (1974) Hydrogen cyanide, a secondary metabolite of Pseudomonas aeruginosa. Can J Microbiol 21:613-618

48. Darby C, Cosma CL, Thomas JH, Manoil C (1999) Lethal paralysis of Caenorhabditis elegans by Pseudomonas aeruginosa. Proc Natl Acad Sci U S A 96:15202-15207

49. Gallagher LA, Manoil C (2001) Pseudomonas aeruginosa PAO1 kills Caenorhabditis elegans by cyanide poisoning. J Bacteriol 183:6207-6214

50. Wei S, Guo Z, Li T, Zhang T, Li X, Zhou Z, Li Z, Lui M, Luo R, Bi D, Chen H, Zhou R, Jin H (2012) Genome sequence of Mycoplasma iowae strain 695, an unusual pathogen causing deaths in turkeys. J Bacteriol 194:547-548

51. Duane PG, Rubins JB, Weisel HR, Janoff EN (1993) Identification of hydrogen peroxide as a Streptococcus pneumoniae toxin for rat alveolar epithelial cells. Infect Immun 61:4392-4397

52. Hirst RA, Sikand KS, Rutman A, Mitchell TJ, Andrew PW, O'Callaghan C (2000) Relative roles of pneumolysin and hydrogen peroxide from Streptococcus pneumoniae in inhibition of ependymal ciliary beat frequency. Infect Immun 68:1557-1562

53. Garsin DA, Sifri CD, Mylonakis E, Qin X, Singh KV, Murray BE, Calderwood SB, Ausubel FM (2001) A simple model host for identifying Gram-positive virulence factors. Proc Natl Acad Sci U S A 98:10892-10897

54. Pericone CD, Overweg K, Hermans PW, Weiser JN (2000) Inhibitory and bactericidal effects of hydrogen peroxide production by Streptococcus pneumoniae on other inhabitants of the upper respiratory tract. Infect Immun 68:3990-3997

55. Techasaensiri C, Tagliabue C, Cagle M, Iranpour P, Katz K, Kannan TR, Coalson $\mathrm{J}$, Baseman JB, Hardy RD (2010) Variation in colonization, ADP-ribosylating and vacuolating cytotoxin, and pulmonary disease severity among Mycoplasma pneumoniae strains. Am J Respir Crit Care Med 182:797-804

56. Johnson C, Kannan TR, Baseman JB (2009) Characterization of a unique ADPribosyltransferase of Mycoplasma penetrans. Infect Immun 77:4362-4370

57. Flint A, Sun Y-Q, Stintzi A (2012) Cj1386 is an ankyrin-containing protein involved in heme trafficking to catalase in Campylobacter jejuni. J Bacteriol 194:334-345
58. Carter GP, Cheung JK, Larcombe S, Lyras D (2014) Regulation of toxin production in the pathogenic clostridia. Mol Microbiol 91:221-231

59. Matson JS, Withey JH, DiRita VJ (2007) Regulatory networks controlling Vibrio cholerae virulence gene expression. Infect Immun 75:5542-5549

60. Neilan BA, Pearson LA, Muenchhoff J, Moffitt MC, Dittmann E (2013) Environmental conditions that influence toxin biosynthesis in cyanobacteria. Environ Microbiol 15:1239-1253

\section{Submit your next manuscript to BioMed Central and take full advantage of:}

- Convenient online submission

- Thorough peer review

- No space constraints or color figure charges

- Immediate publication on acceptance

- Inclusion in PubMed, CAS, Scopus and Google Scholar

- Research which is freely available for redistribution 